УдК 659.1:637.134(477.46)

O. Pen'kova,

Doctor of Economic Sciences, Associate Professor, Head of the Department of Marketing, Uman

National University of Horticulture

ORCID ID: 0000-0002-7213-9824

A. Kharenko,

PhD in Economics, Associate Professor, Associate Professor of the Department of Marketing, Uman National University of Horticulture

ORCID ID: 0000-0003-1240-0944

V. Nevlad,

PhD in Economics, Associate Professor, Associate Professor of the Department of Marketing, Uman

National University of Horticulture

ORCID ID: 0000-0002-3305-9557

DOI: $10.32702 / 2306-6814.2020 .15-16.22$

\title{
ADVERTISING CONCEPTS OF THE PROMOTION OF THE PRODUCTION OF MILK PROCESSING ENTERPRISES IN CHERKASY REGION
}

\author{
О. Г. Пенькова, \\ А. е. н., доцент, завідувач кафедри маркетингу, Уманський національний університет садівництва \\ А. О. Харенко, \\ к. е. н., доцент, доцент кафедри маркетингу, Уманський національний університет садівництва \\ В. Ф. Невлад, \\ к. е. н., доцент, доцент кафедри маркетингу, Уманський національний університет садівництва
}

РЕКААМНІ КОНЦЕПЦІЇ ПРОСУВАННЯ ПРОАУКЦІЇ МОАОКОПЕРЕРОБНИХ ПІАПРИЕМСТВ ЧЕРКАСЬКОÏ ОБ $\Lambda$ АСТI

Peculiarities of advertising concepts of milk processing enterprises in Cherkasy region were demonstrated in the article and the evaluation of the level of their perception by consumers was done. It was determined that all milk processing enterprises of the region have their own advertising concept and systematic character of extension and defining channels of the extension of advertising applications are determined by the extent of activity of certain producers of goods and by location of sales markets with their production, financial possibilities, belonging to corporative joining, purpose and consequently channels of production realization.

Using a monographic research method, it was found that the full range of marketing communications and advertising channels is used by only four powerful companies in the region, which products are presented at national or regional markets and bigger part of the assortment is intended for final consumption. It is proved that they have in common brand-oriented advertising campaigns for individual product positions, lack of segmentation of the target audience and clear competitive positioning.

A study of the impact of advertising on the choice of consumers of dairy products in Uman, Cherkasy region using the survey method showed that for $38.4 \%$ of respondents it has no effect and only for $26 \%$ it is the main factor in making a purchase decision. The analysis of the level of memorization of advertising of products of powerful dairy enterprises of Cherkasy region revealed that $27.7 \%$ of 
respondents could not remember the advertising of any of these producers, $34 \%$ remembered the advertising of all, and the distribution of the number of respondents who mentioned advertising of each brand enterprises are proportional to their presence in the information space. A study of the level of perception of advertising demonstrated that only for the products of one brand, the percentage of consumers - respondents who remembered advertising and positively perceived it almost coincides. It is concluded that significant differences in the levels of memorization and levels of perception of advertising of products of other brands of dairy enterprises in Cherkasy region indicate the need to revise their advertising concepts.

У статті висвітлено особливості рекламних концепцій молокопереробних підприємств Черкаської області та здійснено оцінку рівня їх сприйняття споживачами. Визначено, що всі молокопереробні підприємства області мають власну рекламну концепцію, а систематичність розповсюдження і вибір каналів поширення рекламних звернень визначається масштабами діяльності окремих товаровиробників та географією ринків збуту їх продукції, фінансовими можливостями, приналежністюдо корпоративних об'єднань, призначенням і, відповідно, каналами реалізації продукції.

З використанням монографічного методу дослідження з'ясовано, що повний спектр маркетингових комунікацій і каналів поширення рекламних звернень використовують лише чотири потужних підприємства області, продукцію яких представлено на загальнонаціональному або регіональному ринках і більшу частину асортименту яких призначено для кінцевого споживання. Доведено, що спільними для них є бренд-орієнтовані рекламні кампанії для окремих товарних позицій, відсутність сегментації цільової аудиторії і чіткого конкурентного позиціонування.

Дослідження впливу реклами на вибір споживачів молокопродуктів міста Умань Черкаської області з використанням методу анкетного опитування показало, що на 38,4\% респондентів вона не має впливу і лише для $26 \%$ вона є основним чинником при прийнятті рішення про купівлю. Аналіз рівня запам'ятовування реклами продукції потужних молокопереробних підприємств Черкаської області виявив, що 27, $7 \%$ респондентів не змогли пригадати реклами жодного з цих виробників, 34\% запам'ятали рекламу усіх, а розподіл кількості респондентів, які згадали рекламу товарів торгових марок кожного окремого підприємства пропорційний їх присутності в інформаційному просторі. Дослідження ж рівня сприйняття реклами показало, що лише для продукції одного бренда відсоток споживачів - респондентів, які запам'ятали рекламу і позитивно її сприйняли майже співпадає. Зроблено висновок, що значні розбіжності у рівнях запам'ятовування і рівнях сприйняття реклами продукції інших торгових марок молокопереробних підприємств Черкаської області вказують на необхідність перегляду їх рекламних концепцій.

Key words: milk processing enterprises, advertisement, advertising concept, advertising application, level of memorization of the advertisement, level of perception of the advertisement.

КлючоВі слоВа: молокопереробні підприємстВа, реклама, рекламна концепція, рекламне зВернення, ріВень запам'ятоВуВання реклами, ріВень сприйняття реклами.

\section{DEFINING THE PROBLEM}

The market of dairy products is quite saturated, it has a large number of products from different manufacturers that have approximately the same quality characteristics. Thus, milk processing companies operate in markets that have the characteristics of markets of pure and monopolistic competition at the same time. Within the strategic group, which unites producers that produce and sell goods of similar quality, the possibilities of their marketing pricing policy are limited. All this forces businesses to look for opportunities to express themselves to potential consumers and business partners. Attempts to replace communication activity with increasing commercial efforts, similar to the extensive increase in the presence of consumers in the information space, do not give the desired and long-term effects. In addition, the formation of a positive image of a brand directly depends on how creative and thoughtful the concept of product advertising is.

\section{ANALYSIS OF THE LATEST RESEARCH AND PUBLICATIONS}

We can fully agree with the opinion of Y.V. Sidorenko that in conditions of oversaturation of markets with goods and services and the intensification of crisis phenomena in economic life, theoretical and applied principles of advertising psychology become an important driver of goods promotion, and as a consequence - strengthening 


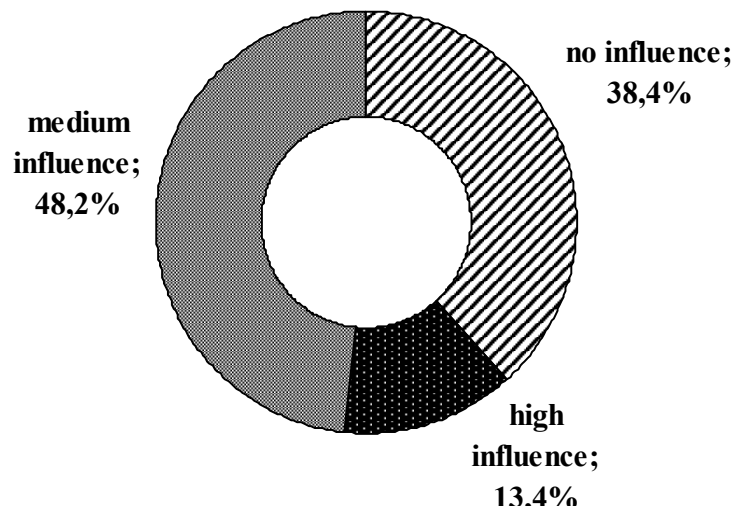

Fig. 1. Consumers evaluation of advertising influence on making decisions towards purchasing dairy products

competitive positions [1, p. 23]. At the same time, the sharpening of competition in the national market of dairy products, according to O.V. Pyankova, makes virtually no alternative way of brand development of enterprises, which is based on consumer needs [2, p. 32]. L. Yu. Lufrenko considering the mechanism of formation of advertising campaigns of milk processing enterprises, emphasizes its complexity and variety [3, p. 454] and notes that the comprehensive and consistent implementation of advertising activities developed in the context of brandoriented advertising strategy, allows to obtain a much greater communication effect than individual, unrelated to a common goal and separated in time [4, p. 182]. It is confirmed by the results of a survey by N.R. Kurbak, who polled the residents of Lviv region, according to which $49.2 \%$ of respondents determined that their choice of dairy products is influenced by brand awareness and $13 \%$ are influenced by advertising [5, p. 92]. According to the research by O.V. Smolyanyuk, the reduction of communication activity, as well as the presence in trading networks, significantly and negatively affects the position and value of their brands for most dairy companies [ 6 , p. 197]. The presence of a significant positive impact of advertising on the income of dairy producers has been established by foreign researchers $[7 ; 8]$, but it is mentioned that for different products (milk, cheese) the effectiveness of advertising costs differ significantly.
Besides, their effectiveness mostly depends on the creativity of advertising campaigns of individual manufacturers.

\section{FORMULATION OF ARTICLE AIMS}

The aim of the following article is the research of advertising concepts of milk processing enterprises in Cherkasy region and the level of their perception by consumers.

\section{PRESENTATION OF THE MAIN \\ INFORMATION OF THE RESEARCH}

From the point of view of the organization of product distribution, all milk processing enterprises of Cherkasy region can be divided into two groups: those that make decisions independently and those that are a part of corporate associations with central services for finance, marketing, etc.

The first category includes small processing shops (the decision is made by the owner), PJSC "Zvenigorodka Cheese Plant" (sales department), PJSC "Yuriia" (marketing, logistics, sales and commercial departments are responsible for certain aspects of product distribution), PJSC "Kaniv Butter and Cheese Plant "(sales and export departments).

The second category includes ALC "Zolotonosha Oil Plant" and companies of the "Agropolis" campaign group.

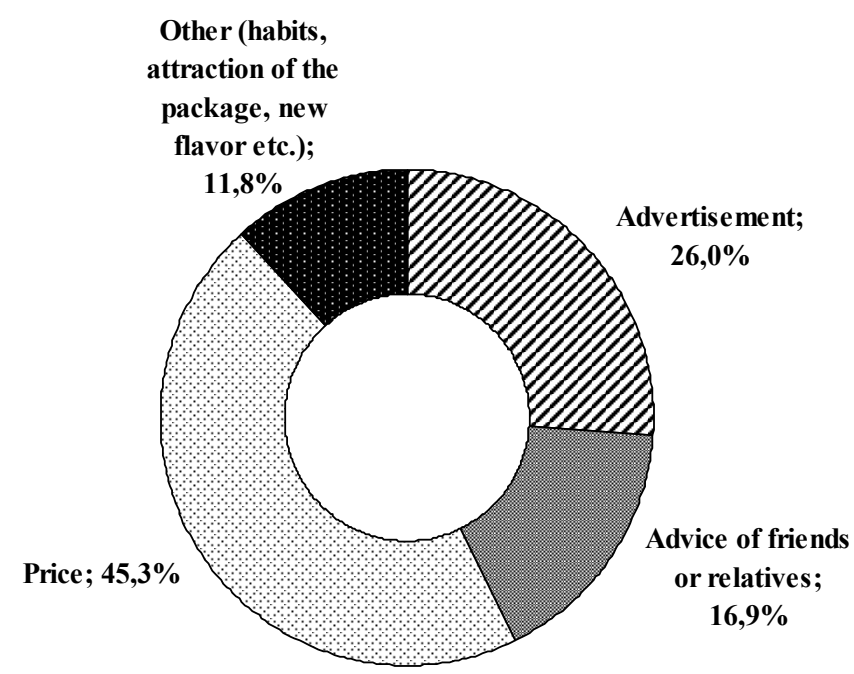

Fig. 2. The main factors of influence on making decisions by consumers about buying dairy products 
Table 1. Characteristics of television advertising of trademarks of milk processing enterprises in Cherkasy region on national channels

\begin{tabular}{|c|c|c|c|}
\hline Trademark & Advertising motto & \begin{tabular}{|c|} 
The main \\
advertising message
\end{tabular} & TV-channel \\
\hline Voloshkove pole & $\begin{array}{l}\text { Delicious as in childhood } \\
\text { Voloshkove pole for } \\
\text { everyone } \\
\text { Voloshkove pole - live } \\
\text { product }\end{array}$ & $\begin{array}{l}\text { Qualitative, useful } \\
\text { products for } \\
\text { everyday meals }\end{array}$ & $\begin{array}{l}\text { STB, New } \\
\text { Channel }\end{array}$ \\
\hline Cheese Club & $\begin{array}{l}\text { Traditions united by flavor } \\
\text { Established for delight }\end{array}$ & $\begin{array}{l}\text { Unique flavor, } \\
\text { technologies of } \\
\text { production }\end{array}$ & $\begin{array}{l}\text { STB, New } \\
\text { Channel, } \\
\text { Ukraiina }\end{array}$ \\
\hline KANIV 1971 & $\begin{array}{l}\text { Quality without } \\
\text { compromises }\end{array}$ & $\begin{array}{l}\text { Traditional recipes, } \\
\text { achievable prices }\end{array}$ & $\begin{array}{l}\text { M1, New } \\
\text { Channel, } \\
\text { Ukraiina, } \\
\text { Inter }\end{array}$ \\
\hline Zveni Hora & $\begin{array}{l}\text { Proficiency that comes with } \\
\text { time }\end{array}$ & $\begin{array}{l}\text { Quality, convenient } \\
\text { package }\end{array}$ & STB, Inter \\
\hline Pyriatyn & $\begin{array}{l}\text { Do not waste a minute, taste } \\
\text { to the last moment } \\
\text { Pyriatyn Cheese is always } \\
\text { with milk }\end{array}$ & $\begin{array}{l}\text { Diversity of flavors, } \\
\text { convenient package; } \\
\text { it unites cheese } \\
\text { lovers }\end{array}$ & $\begin{array}{l}\text { NLO TV, } \\
\text { ICTV, Inter, } \\
1+1\end{array}$ \\
\hline
\end{tabular}

Thus, the first plant is a part of the group of companies "Molochnyi Alians", where the distribution of products in the domestic market is a specialized unit, built on a regional basis (has a central of fice and regional of fices - northeast region, western region, southern region, southeastern region, central region). A separate division is engaged in export of production. In its turn, Agropolis uses a network of distributors and its own sales department to sell its products.

Dairy enterprises of the region that was being studied, regardless of the size, carry out various measures to promote products to the market. The use of marketing tools depends on the financial condition of economic entities and the scale of their activities. However, according to the research, each of them has its own advertising concept.

The survey was conducted at the exit of supermarkets and grocery stores (ATB, Velmart, Furshet) in Uman, Cherkasy region in May - June 2020 to determine the impact of advertising on consumer choice. The total sample was 112 people aged $19-67$ years. For a significant number of respondents -43 people, mostly middle-aged and elderly, advertising has no effect (Fig. 1).

Regarding the factors used by the surveyed buyers of dairy products (the question provided a single answer of respondents), the most important for 51 people is the price, for 29 - advertisement, for 19 - the advice of friends or relatives, for 13 - other (Fig. 2).

Manufacturers use advertising in trading networks, outdoor advertising, TV advertising, advertising on social networks and on their own sites among the channels of distribution of advertising appeals, but there are some differences in the choice of channels due to the predominant purpose (final or intermediate consumption) and location of markets.

Small private producers that offer a limited range of products (raw milk, cottage cheese, cheese of their own production) and sell it in local markets since last year have begun using social networks actively to promote their own products. This process was intensified due to the disruption of logistics links and the ban on markets during the strict quarantine restrictions in April - May 2020. As a rule, other channels of information dissemination are not used by them.

Only powerful milk processing enterprises in Cherkasy region, products of which are presented on the national or regional markets, systematically use advertising to promote their own products using the most widely used means of communication: television and the Internet. Thus, the widest line of products among the dairy enterprises of the region has PJSC "Yuriia" in Cherkasy (trademark "Voloshkove Pole"): the width of the product-mix -

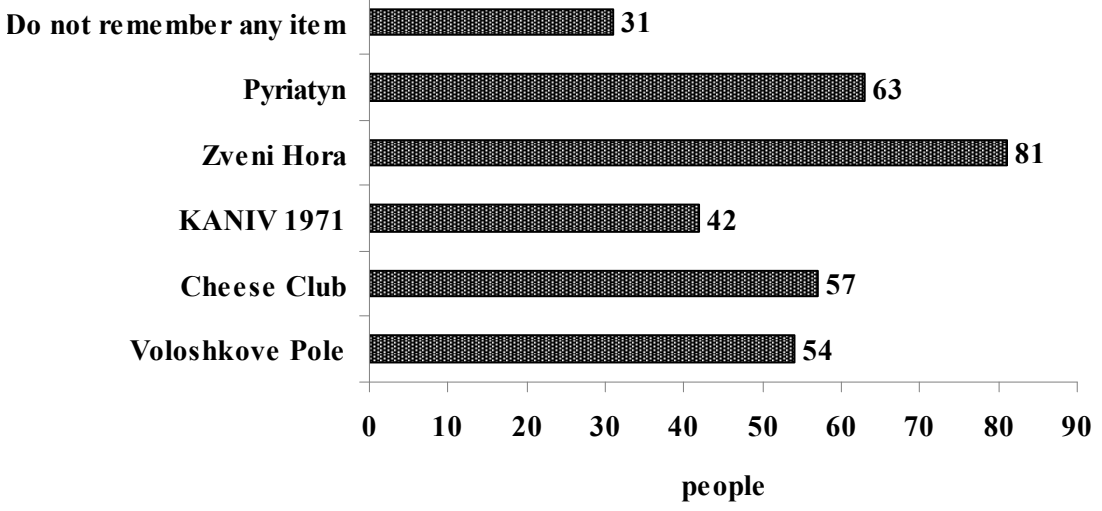

Fig. 3. The level of memorization of products advertising by consumers-respondents 


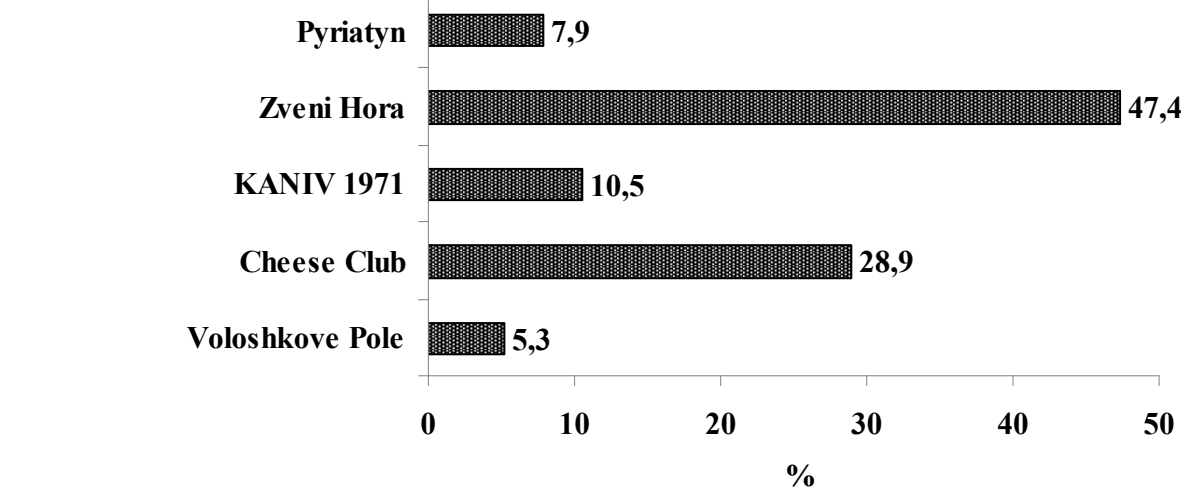

Fig. 4. The level of perception of advertising of products of milk processing enterprises in Cherkasy region by consumers-respondents

10 items, the length -3.2 . The key items that are included into group $A$ of the company's products according to the $A B C$ analysis are milk, butter, yogurt, sour cream and kefir. Advertising of individual product items distributed over time, is reminiscent, is designed for all categories of consumers and emphasizes the usefulness and quality of products (Table 1).

ALC "Zolotonosha Oil Plant" is a part of the group of companies "Molochnyi Alians" and produces products of 7 groups, two of which were established in 2018. The company's products are sold under several brands "Zlatokray", "Pyriatyn", "Slavia" and "Molochnyi Alians". Under the first brand butter is sold, and the next two brands are presented by cheese (other types of production of these brands are made by other enterprises of the group).

Trademark "Zlatokray" is a regional brand, and is intended for the sale of products mainly to catering establishments and organizations that procure through tender procedures. It causes a lack of direct product advertising.

The cheese of "Pyryatyn" and "Slavia" trademarks, which are also produced by LAC "Zolotonosha ButterMaking Plant" are sold throughout Ukraine, but only those kinds of products that are produced under the first brand are actively advertised by the media. At the same time, as media monitoring has shown, there is a variability of commercials using different slogans, where the emphasis is on the diversity of tastes and the call for everyday consumption. A characteristic feature of their common style is the dynamics, drive and the presence of elements of humor, which indicates the predominant focus of advertising appeals to the youth segment and middle-aged people.

The Molochnyi Alians brand is used directly for whey powder, skimmed milk powder and whole milk powder, butter (20 kg packing), consequently products that are used mainly for intermediate consumption. It leads to the concentration of advertising efforts in the field of popularization of the whole group of companies, rather than the trademark of individual products, as well as advertising mainly on specialized sites related to the food industry and profiles on social networks.

PJSC "Zvenigorod Cheese Plant" has only one brand "Zveni Gora", under which it produces four main product groups: butter, cheese, processed cheese, cottage cheese.
The main advertising efforts are aimed at promoting processed cheese and cheese, which are key products of the company (about $70 \%$ of sales revenue) and it may indicate the company's desire to maintain regional leadership in this market segment. A single ethnic style combines different commercials, and the main emphasis is made on the experience that provides proficiency.

PJSC "Kaniv Butter and Cheese Plant" specializes in the production of cheese, produced under the trademarks "Cheese Club" and "KANIV 1971". The products of the first brand are mainly designed for consumers (gourmets) with high and medium incomes, while the second - for the middle price segment. The company concentrates its main advertising efforts on promoting the products of the first brand and the main message for consumers is the uniqueness of taste and production technology. Periodic advertising of KANIV 1971 cheese is much lower, and the emphasis is on quality and affordable prices.

Common to TV advertising of all manufacturers is the emphasis on quality and taste, mentioning the brand and advertising only certain products from the entire range, as well as (except for "Pyriatyn" trademark) addressing advertising to all potential consumers without highlighting individual segments.

The analysis of the level of memorization of advertising by respondents has shown that 31 people out of 112 do not remember (or have not seen) advertising of any of the analyzed brands (Fig. 3). The advertising of products of the trdemark "Zveni Hora" was remembered the most.

Only 38 people, out of the total sample of respondents, remember the advertising of dairy products of all these brands. The results of a single choice of the most successful product advertising by these consumers has shown that $47.4 \%$ ( 18 people) believe that it is the advertising of "Zveni Hora" trademark (Fig. 4). Advertising of Voloshkove Pole trademark products gained the least number of supporters - $5.3 \%$.

At the same time, respondents, who liked the advertising of Zveni Hora trademark products, almost proportionally belong to different age categories. Among connoisseurs of advertising of products of "Pyriatyn" trademark, all people are of young age. It is worth noting, that despite the high memorability of advertising of this brand, a significant number of respondents have not given their preference, which may indicate poor positioning. 3 young people (19-34 years old) and 7 middle-aged people 
(42-46 years old) have positively assessed the advertising of Cheese Club trademark products. Respondents have been evenly distributed between the young and middle-aged people segments, who have positively assessed the advertising of KANIV 1971 products, while the age of fans of Voloshkove Pole advertising is between $39-52$ years old.

\section{CONCLUSION}

Dairy enterprises of Cherkasy region actively use advertising to promote their products on the market. The regularity of distribution and choice of channels for the distribution of advertising appeals is determined by the scale of individual producers and the location of markets for their products, financial capabilities, membership in corporate associations, purpose and, accordingly, sales channels.

The full range of marketing communications and channels of distribution of advertising appeals is used by only four powerful enterprises of the region, products of which are presented at the national or regional markets and most of the range of which is intended for final consumption. Common to them are branded advertising campaigns for individual product lines, the lack of segmentation of the target audience and clear competitive positioning.

The research of the impact of advertising on the choice of consumers of dairy products in Uman, Cherkasy region has shown that $38.4 \%$ of respondents have no influence and only for $26 \%$ of respondents advertising is the main factor in making a purchase decision.

The analysis of the level of memorization of advertising of products of powerful dairy enterprises of Cherkasy region revealed that $27.7 \%$ of respondents could not remember the advertising of any of these producers, $34 \%$ remembered the advertising of all, and the distribution of the number of respondents, who mentioned advertising of each brand enterprises are proportional to their presence in the information space. The research of the level of perception of advertising has shown that only for the products of one brand, the percentage of consumersrespondents, who remembered advertising and positively perceived it almost coincides. Significant differences, that are observed in the levels of memorization and perceptions of advertising of products of other brands of dairy enterprises in Cherkasy region, indicate the need to revise their advertising concepts.

\section{Література:}

1. Сидоренко Ю.В. Динаміка конкуренції: економіко-психологічний концепт реклами. Проблеми і перспективи розвитку підприємництва. 2017. № 2. С. 2226.

2. П'янкова О.В. Обгрунтування напрямів розвитку брендів підприємств молочної промисловості відповідно до "Піраміди ієрархії потреб споживачів у продуктах харчування та напоях, що представлені під брендами" / / Зб. наук. праць Черкаського державного технологічного університету (Серія: Економічні науки). 2012. Вип. 31. 4. 2 Т. 2. С. $31-38$.

3. Луференко Л.Ю. Механізм фрормування рекламних кампаній молокопереробних підприємств. Економічні науки. Сер.: Облік і фрінанси. 2013. Вип. 10 (3).
C. 446-454. URL: http://nbuv.gov.ua/UJRN/ecnof_2013_10(3)_ 75

4. Луференко Л.Ю. Бренд-орієнтована рекламна діяльність молокопереробних підприємств. Вісник Хмельницького національного університету. Економічні науки. 2014. № 1. С. 182-185.

5. Кубрак Н.Р. Конкурентні переваги виробників на ринку молокопродуктів України. Науковий вісник Херсонського державного університету. Сер.: Економічні науки. 2018. Вип. 31. С. 90-95.

6. Смолянюк О.В. Інтернет-комунікації у маркетингу молокопереробних підприємств. Економіка: реалії часу. 2014. № 6. С. 193-198.

7. Charles F. Nicholson, Harry M. Kaiser (2008) Dynamic market impacts of generic dairy advertising. Journal of Business Research. vol. 61 (11). p. 1125-1135.

8. Todd M. Schmit, Diansheng Dong, Chanjin Chung, Harry M. Kaiser, Brian W. Gould. 2002. Identifying The Effects Of Generic Advertising On The Household Demand For Fluid Milk And Cheese: A Two-Step Panel Data Approach. Journal of Agricultural and Resource Economics. Western Agricultural Economics Association. vol. 27 (1). p. $1-22$.

\section{References:}

1. Sydorenko, Yu. V. (2017), "Dynamics of competitiveness: economical and psychological concepts of advertising", Problems and prospective of the development of enterprising, vol. 2, pp. 22-26.

2. Piankova, O. V. (2012), "Reasoning of the directions of brands of milk industry development according to the "The pyramid of hierarchy of consumers' needs in food products and beverages, which are presented under these brands", Cherkasy State Technological University, vol. 31, no. 2, pp. 31-38.

3. Lufrenko, L. Yu. (2013), "Mechanism of formation of advertising campaigns of milk processing enterprises", Economic sciences. Accounting and finance, 2013, vol. 10(3), pp. 446-454, Available at http://nbuv.gov.ua/ UJRN/ecnof_2013_10(3)__75 (Accessed 10 Aug 2020).

4. Lufrenk̄o, L. $\overline{Y u} .(2014)$, "Brand-oriented advertising activity of milk processing enterprises", A reporter of Khmelnytskyi National University. Economic sciences, 2014, vol. 1, pp. 182-185.

5. Kubrak, N. R. (2018), "Competitive advantages of producers at the milk processing market of Ukraine", A scientific reporter of Kherson State University. Economic sciences, 2018, vol. 31, pp. 90-95.

6. Smolianiuk, O. V. (2014), "Internet communications in marketing of milk processing enterprises", Economics: reality of time, vol. 6, pp. 193-198.

7. Nicholson, C. F. and Kaiser, H. M. (2008), "Dynamic market impacts of generic dairy advertising", Journal of Business Research, vol. 61 (11), pp. 1125-1135.

8. Schmit, T. M. Dong, D. Chung, C. Kaiser, H. M. and Gould, B. W. (2002), "Identifying The Effects Of Generic Advertising On The Household Demand For Fluid Milk And Cheese: A Two-Step Panel Data Approach", Journal of Agricultural and Resource Economics. Western Agricultural Economics Association, vol. 27 (1), pp. 1-22.

Стаття надійшла до редакиї 21.08.2020 p. 